\title{
Embodied leadership: Paradigm shifts in the leadership of a local URCSA congregation
}

\begin{abstract}
In South Africa the religious sector, through its leadership, has in the past and can still make a significant contribution to the transformation agenda, particularly by fostering leadership relationships across ethnic, cultural and socio-economic divides (bridging and linking social capital). Ethnographic empirical research into the leadership narratives of the Vlottenburg Uniting Reformed Church in Southern Africa, Stellenbosch, showed how the leadership in this congregation moved through different leadership paradigms in a relatively short time. An investigation using different theoretical frames was undertaken in an attempt to understand the impact that socio-cultural changes had on the functioning of the leadership in the congregation. The research also investigated the transformative influence the leadership had on the embodied ecclesiology of this congregation in a lowincome socio-economic environment. Some suggestions are made on how the local leadership can cross cultural and socio-economic divides and contribute to South Africa's transformation agenda.
\end{abstract}

\section{INTRODUCTION}

The members of the church council are talking in the consistory before they enter the church for the morning service. An elder stands up and with a few tense words tells the rest of the council how disappointed he was the day before when no other church members arrived to help him dig a trench around the church (as part of the sewerage system). He explains that he had to hire labourers to help him - this after he asked for help during the service the week before to avoid unnecessary costs. He gradually becomes more and more passionate, and before long he is fired up to tell the entire congregation (waiting for the service to start) what he thinks of this tardiness.

A fellow elder stands up and admonishes his brother to stay calm. With a quiet voice he explains that this is not the way to talk to the congregation. The congregation belongs to Christ, not to the elder. It would be better to speak to them kindly, inviting them again, rather than to alienate them with his anger. Another member of the council prays, and we enter the church as the congregation sings a hymn.

I watch the elder tensely as he takes up his position behind the wooden podium. I fear the worst, but he calmly and pleasantly tells the congregation of the work done the day before. He expresses gratitude that he could find labourers to help him dig the trench. Without judgement or criticism he explains to the congregation why the trench is important, and invites them to view the progress after the morning service. The congregation sings another hymn. ${ }^{1}$

11 The mother tongue of the congregation is Afrikaans, which made it possible for the researcher, who is also Afrikaans speaking, to follow the conversations, sermons and hymns with ease. The congregation consists of mainly brown people who speak Afrikaans with a specific Western Cape accent making use of unique idioms, phrases and sayings. If one pages through the hymn book of the URCSA, the "Nuwe 
This short fragment of events before and during the church service of the Uniting Reformed Church in Southern Africa (URCSA) of Vlottenburg gives one a glimpse of the human interaction ${ }^{2}$ in this marginalised congregation between the vineyards on the outskirts of Stellenbosch. ${ }^{3}$ It is through this fragment that we see something of the embodied leadership of this congregation, which was founded within the old mission paradigm and is constantly challenged by changing circumstances to adjust its identity and leadership. ${ }^{4}$ There is undoubtedly strong leadership, despite the fact that they do not have a permanent minister. A relief minister preaches every fortnight and acts as chairperson of the church council. But if one asks the church members who the minister is, they quickly reply that they are 'shepherdless'.

The research question of this study was: In what ways did the socio-cultural changes during the past 20 years have an influence on the change in embodied leadership and leadership paradigms, and did it contribute to the transformation agenda as part of God's mission to the world?

To answer the question I made use of different empirical and theoretical probes in an attempt to understand not only what is happening in the leadership of this congregation (descriptive empirical task), but also why it is happening (interpretive task). In the last section of the article I examine ways in which an embodied leadership can contribute to the transformation agenda within this specific context (normative and pragmatic tasks) (Osmer 2008:4).

\section{2.}

\section{EMBODIED LEADERSHIP}

When I refer to embodied leadership, it is within a context of the so-called postmodern rediscovery of the body. The body as reference framework and identity construct is attracting renewed interest. ${ }^{5}$ Our bodies are in a certain sense our anchors, not only in terms of the appearance and feeding thereof, but also in terms of the public expression of the fact that we are some-body and not just some-one (Cilliers 2007:9). When one considers the fashion awareness of young people, one realises that it is about more than just being 'in' with the peer group, but that it also forms part of their self-understanding and self-realisation in a highly individualistic culture.

From a theological perspective, however, various scholars agree that the so-called anthropological turn in the mid 20th century concurs more with the Semitic (Biblical) anthropology than with the Greek-Hellenistic understanding of the body (Van der Leeuw 1949:9; Lukken 1990:6-7). Bonhoeffer's (1998:33) definition of the church as community is of interest

Sionsgesange" (New Sion hymns), one immediately notices this distinctive use of Afrikaans. Most URCSA preachers also prefer to make use of the 1933 Afrikaans Bible translation, rather than more recent translations.

2 It is these kinds of signals in a faith community that invite a process analysis of the community. Cf. Hendriks (2004:148-151).

3 For similar studies of one specific faith community, see Brouwer (2009) and Osmer (2005), who did an analysis of the URCSA Stellenbosch, Cloetesville, and named the study "Leadership in the spirit of Belhar".

4 The fact that the focus here is on one specific congregation is related to the researcher's conviction that faith communities have the necessary social capital not only to promote social cohesion (bonding and bridging capital) but also to influence the value systems of believers profoundly (linking capital). Congregations have during the centuries illustrated that they have the necessary infrastructure and in most cases they are sustainable. The question (also in this research) is of course the nature and quality of the (theological) leadership and leadership styles practiced in the communities. See also Swart (2010).

5 For example, in June and July 2010, the FIFA Soccer World Cup took place in South Africa. Thousands of bodies from all over the globe were packed into mega-stadiums watching bodies kicking around a ball, with many millions more following each bodily move on television screens. 
here. He refers to Christus als Gemeinde existierend (Christ in the form of the congregation), which concerns divine self-presentation and human re-presentation. The Spirit is body, and without it we cannot experience the presence of God.

In this theological framework the body itself becomes the interpretative action of a person. So, proverbially, I do not only have a body, I am my body. Therefore, God reveals Himself through all our senses, not just one or two of them. The question of course remains which body we are talking about, especially if we want to link it to leadership.

In this regard, Caputo (1993:130) makes an important distinction between what he calls "philosophy's body", which manifests via the ancient philosophers in an active, athletic, healthy, white, male body, and the "distorted body" of lepers, cripple and lame people that reminds of elements of Paul's anthropology and fails the classic paradigm of a 'perfect body'. A theological understanding within the Christian tradition thus brings us to another understanding of the body, namely a broken body that is healed by an Other broken body (Cilliers 2007:12). Caputo (1993:131) expresses this movingly:

... by flesh let us signify everything that is both vulnerable or able to be wounded, which means bent, cut, lacerated, ulcerated, withered, inflamed, paralyzed, numbed, or finally killed, but also healed, bound up, made comfortable and fed, and able to enjoy jouissance.

These bodies of flesh are attracted to Jesus by an almost natural gravitational pull, and he seems literally to be swarmed by them: they brought to him everybody like that ... Surely this is a case of like attracting like, because in the end Jesus ends up as one of these bodies.

The one who has become flesh becomes the most famous case of vulnerable, crucified flesh

(which is also transformed and transfigured) ...

Therefore, one of the implications of such an understanding of the body for embodied leadership is the fact that we are not searching for 'successful' leadership models, strategies or styles. Leadership is not only for the mighty and influential, but, to concur with Kehane (2010:15), is mostly about the "falling and stumbling" of ordinary people. In the case of the URCSA Vlottenburg, the leadership consists of ordinary believers who are chosen by fellow believers to serve in the offices of elders and deacons. ${ }^{6}$

The empirical data (and the interpretation thereof) indicate in various ways how the sociocultural changes not only contributed to the marginalisation of this community, but also how it contributed to the ongoing process of 'brokenness and healing' in the leadership of the faith community. This leaves one with the idea of an ethos of vulnerable interdependence, in which believers are part of the bigger story, the story of a broken (and resurrected) body (Vosloo 2006:31).

\section{3.}

METHODOLOGY FOR EMPIRICAL RESEARCH

Before I begin with a few cursory comments on the background and history of the URCSA Vlottenburg, I want to mention some thoughts about the methodology used in the study. The methods I used for data capturing included the standardised interview, but also discursively oriented interviews, where some of the interviewees, ${ }^{7}$ especially the elderly people, simply told the story of the congregation. I also made use of participatory observation, read some of the minutes of the congregation, made field notes while attending meetings of the church board, paged through the hymnal of the URCSA and read the articles on the offices in the URCSA (cf.

6 In the URCSA there is still much appreciation for the offices of minister, elder and deacon. The

congregation looks up to the church council with respect, which does however not mean that they always agree with its decisions.

7 I use the terms interviewee, respondent, speaker and participant interchangeably. 
Henning 2004:50-79). Generally speaking, one could classify this methodological approach as falling within the wider field of ethnographic studies. ${ }^{8}$

4. SOCIO-CULTURAL CHANGES

The social-cultural changes in South Africa since 1990 are described in various ways. Smit (2008:106) refers to a so-called collapse into modernity to explain that South Africa had to deal with the full impact of globalisation and modernisation in a relatively short time (20 years). De Gruchy and Ellis (2008:9) use another interesting image to describe it. They write that the context since February 1990 (the unbanning of the freedom movement and the release of Mandela) and again after 1994 (the first democratic election in which the ANC came into power) literally meant that we woke up in 'another country'.

In this 'other country' the disintegration/dismantling of the apartheid politics happened so fast that it completely weakened the church's ability to participate in the public discourse on social themes. De Gruchy and Ellis (2008:9) make the following comment about leadership in this regard:

To be sure, Christian leadership drew from what it had learned in the struggle against racism and apartheid to contribute to the themes of peace-making, reconciliation, and nation-building, but the ability to engage with the wider socio-economic and cultural themes of the new nation was lacking".

The story of the leadership in the URCSA Vlottenburg occurs against the background of these radical changes that blew across the congregation like the black southeaster, and still blows from time to time. But it also occurs against the background of the inability of vulnerable (but willing) leaders to address the wider socio-economic and cultural themes (cf. Botman 2008, cited in De Gruchy \& Ellis 2008:8).

\section{A SHORT DESCRIPTION OF THE URCSA VLOTTENBURG}

The URCSA Vlottenburg seceded in 1963 from the URCSA Rhyns, situated in the heart of Stellenbosch. Initially, church services were held in a church hall in Devon Valley church, until the Vlottenburg church building was completed in 1967. The congregation consists of 500 members, with 150 regularly attending church services.

The church building is situated among the vineyards of luxury wine farms on Stellenbosch Kloof Road. ${ }^{9}$ The building is divided in two, with a part for worship on the one side and a church hall on the other. During the pressing season, the hall is let out to seasonal labourers from the Eastern Cape who work in the vineyards every year. ${ }^{10}$ Since the departure of the last minister,

8 Cf. Van de Waal (2009) and Brouwer (2009). See also an applied form of ethnographic studies by Marais and Taylor (2007).

9 The "history of inequality" (cf. Terreblanche 2002) is very prominent in this area with some of the largest wine farms in the Stellenbosch environment but also some of the poorest people in the province and a very high percentage of children born with foetal alcohol syndrome (FAS). Visit http://fasfacts.org.za for more information. From the website the following quote: "The continued focus of research based on communities such as Wellington in the Western Cape Province, and De Aar and Upington in the Northern Cape Province, once again underscored the enormity of the FAS problem in South Africa. The severity of the potential crisis facing the country is best illustrated by the results from the De Aar project that show a prevalence of FAS in the town of 122 per 1000 school-entry children, thus $12,2 \%$. This is officially the highest frequency yet reported in one population anywhere in the world".

10 From this the conclusion can be drawn that $90 \%$ of the members are labourers who work on wine farms around Stellenbosch, including the areas Devon Valley, Stellenbosch Kloof, Stellenbosch Hills, 
the manse is let out. The church board has been managing the weekly ministerial activities with the help of a relief minister ${ }^{11}$ for the past 10 years, which means that most of the ministry (preaching, pastoral care, teaching) is done by members of the church council (local elders and deacons).

Across the road from the church is the Methodist Church and next to it is a general dealer selling everyday goods. Behind the church is a community of sub-economic housing for mostly farm labourers. Nearby is Vlottenburg Primary School with some 500 learners from Grade 1 to Grade 9. Further down the road from the school is a Vineyard congregation. ${ }^{12}$ Many of the members are bussed in from various farms in the area for church services on Sundays. The bus departs again at a specified time, which means the service has a time limit. ${ }^{13}$

The most important identity markers of the congregation are to be found in the services on Sundays, the choir consisting of 25 members, ${ }^{14}$ the youth movement and the women's guild. Various festivals in the course of the year offer a further window on the faith community, including the church fête, the choir competition, Pentecostal services, and so forth. Regular congregation meetings give members the opportunity to be heard and group visits to the nine different wards ensure firsthand knowledge of needs and pastoral problems.

\section{6.}

\section{THE LEADERSHIP NARRATIVE}

Although the leadership narrative of this community is unique, it is not so unique that many other faith communities will not recognise themselves in the narrative. From the empirical data it is very clear that the story of the congregation since its founding is closely linked to the ministers who served in the congregation. Particularly older members nostalgically long for the early days of the congregation, and they can remember the first ministers in extraordinary detail. I divide the history into three phases, metaphorically making use of three concepts homeland, independent and 'another country'.

\subsection{Homeland phase}

I use this concept because the congregation was founded in a time when apartheid theology was still flourishing and the so-called homeland policy, with the emphasis on separate development, had strongly taken root in church circles. ${ }^{15}$ During this time, evangelists, paid by 'mother congregations', ministered in many congregations similar to the URCSA Vlottenburg. The first evangelist (who according to one interviewee did excellent work) was later replaced by two white ministers $(A \text { and } B)^{16}$ who altogether ministered for nearly 20 years in the congregation. Their salaries were also paid by the DRC.

The respondents (particularly older members) have good memories of these days; in their

Vlottenburg, Lynedoch, and so forth.

11 A relief minister is a minister that acts on behalf of the circuit when there is not a permanent minister in the congregation.

12 The Vineyard is a charismatic group with congregations world-wide.

13 The Western concept of time in which a service must be completed within an hour does not apply in most URCSA congregations. Because a private bus service is used, and the driver must have the bus back at the depot at a certain time, the length of the church service is limited.

14 Choir outfits create a unique identity.

15 The history of the well-known 1861 Synodical decision of the Dutch Reformed Church (DRC) shows that racial separation was a practice in the DRC family long before the political developments that led to apartheid.

16 For the sake of confidentiality, the letters of the alphabet are used for the different ministers that served in the congregation. 
interviews they used words like "true soul-winners", making one aware of the "language of warm-hearted piety", which is one of the characteristics of the URCSA spirituality (cf. Osmer 2005:151). The financing of congregational expenses was mostly done through generous donations from some of the wine farmers, most of them members of the DRC Stellenbosch West, who supported this so-called daughter congregation from the start.

\subsection{Independent phase}

According to the empirical data, a new phase dawned in the congregation with the arrival of Minister C in 1990. He was a member of the URCSA and completed his theological studies at the University of the Western Cape under teachers such as Dr Allan Boesak and Prof Gustav Bam. From the start it was clear that his theological principles would position him and the church council in a new relationship with the 'mother church'. Without going into unnecessary detail, it was clear that he was not prepared to tolerate the servile, dependent labourer relationship towards the farmers, and within the first month of his ministry he ended all ties with the DRC.

Particularly the relationship with the DRC Stellenbosch West, which was the minister's main source of income, deteriorated dramatically during this phase. In this time a manse was built next to the church hall. The sudden increase in debt and decrease in income as a result of the deteriorating relationship with the mother church not only put the congregation in a difficult financial position, but also increased the levels of conflict. Church attendance declined dramatically and eventually Minister C accepted a call to another congregation in $1998 .{ }^{17}$

In 1999 the congregation appointed Minister D as tentmaker. He was appointed by the Presbytery committee as youth minister for the entire presbytery, and worked part-time at the URCSA Vlottenburg. With his unique gifts of preaching and a charismatic spirituality, he managed to fill up the pews again. He also started a gospel band to lead the praise and worship and was himself musically gifted. ${ }^{18} \mathrm{He}$ was only in the congregation for a year, but left a strong heritage and the respondents all have very good memories of his ministry in the congregation. At the end of the year he accepted a call to another congregation.

\subsection{The phase of 'another country'}

I make use of the concept of De Gruchy and Ellis (2008) of 'another country', but adjust their use of the concept to describe a new phase of leadership in the congregation since the end of the 90s. This is the phase in which the local leaders (with the aid of relief ministers) started featuring strongly. The difficult financial position of the congregation and the accompanying conflict had the result that certain prominent families started taking the lead. While it can on the one hand be seen as a positive development in the light of the importance of lay leadership in the church, it was not without complications.

Longstanding feuds between these families became part of the church politics and to this day contribute to regular conflict. This was clearly visible during participant observation in various meetings. What is also significant is that the conflict is not hidden or suppressed. Sometimes the chairperson struggles to keep order. In this regard the relief minister plays an important role, but

17 The call to another congregation was surrounded by controversy. The congregation owed him money for unused leave, pension, and so forth, and the church council was under tremendous pressure in the coming years to rid itself of this burden of debt. In the interviews the hurt involved was evident. It had the further effect that the congregation since then has never been able or indeed wanted to call a full-time minister.

18 One of the respondents in the interviews was a minister with more than 30 years' experience of ministry in the URCSA. He reported that he has found that poor communities are very susceptible to both liberation theology (freedom from oppression) and charismatic or Pentecostal forms of theology (as an escape from a life of poverty). 
he does not come out of these battles unscathed. From the brief leadership narrative, one can recognise the following elements of the ethos of the congregation.

\subsection{Pietism and renewal}

In the church services one finds a warm-hearted piety, expressed in the music, hymns, worship, prayers and Scripture readings. There is also a deep yearning for revival in the congregation. One of the elders told of how a few of them 12 years ago literally stretched themselves out on the floor before the pulpit in an attitude of prayer and prayed for revival long and seriously. In the following weeks, Minister D began to work in the congregation, and his ministry led to a revival in the congregation. This remains part of the genetic code of the congregation and is particularly relived and kept alive by the annual Pentecostal services.

\subsection{Participation and decentralisation}

One of the outstanding characteristics of the congregation is the participation by the church council and various members in worship services and other congregational activities. The arrangement of the worship service is not that of a "dominee se kerk" (minister's church), as almost everyone participates in the service: The elders do the preaching themselves, ward members make the announcements, children take up the offerings, the choir leads the singing, and so forth. The congregational fête, group home visits, youth outreaches and other activities offer more opportunities for membership involvement.

\subsection{Marginalisation and dependency}

Most of the members' physical participation in church activities is defined by various forms of dependence - dependence on the goodwill of the farm owner, particularly during press time in the vineyards, dependence for transport (private and public) and dependence on one another for pastoral support and accompaniment.

All of this makes this community a vulnerable one, largely at the mercy of powers over which they have no control. But, as clearly emerged from the narrative of the leadership, it does not leave them without agency (De Gruchy 2003:20-39). They refuse to be victims of their circumstances and accept the responsibility wholeheartedly.

\subsection{Families and conflict}

From the leadership story it is clear that families play a large role in these types of congregations. The central position of 'fatherly' (and 'motherly') figures from the more influential families (who act as patriarchs and matriarchs and exert control over programmes and finances) emerged clearly in the research. It was also obvious that they do not always agree, which often leads to conflict, as discussed above.

\subsection{Engagement with wider socio-economic and cultural changes}

The leadership story shortly narrated above also makes it clear that engagement with wider socio-economic and cultural changes is not always simple. When a faith community finds itself in a kind of battle for survival, there is not always enough energy and expertise to address the

19 The list of elements is not extensive. The elements discussed came from a content analysis of the interviews and the document analysis of minutes, bulletins, and so forth. My aim was to combine themes that relate to one another. 
greater socio-economic challenges and to react to cultural challenges. I next strive to interpret aspects of the narrative with the aid of Manuel Castells's distinctions concerning identity.

\section{8.} THE POWER OF IDENTITY

In Castells's (2004) second book of his trilogy, he describes the changes that took place in late modernity. This includes the combined impact of globalisation, technology and informalisation. It is especially the flood of information through the Worldwide Web that reconstructs the economy (capitalism) and community. This has created a new world that he calls the "network society", a drama in which social movements are the main actors.

These social movements ${ }^{20}$ construct identity. Die basic hypothesis is that the social construction of identity and the content of that identity take place in a context characterised by power balances. According to him, identity is formed in three ways, and I relate these to the narrative of the URCSA Vlottenburg.

Legitimising identity: This form of identity is shaped by civil society and is usually created by the dominant institutions in society and those in positions of authority. It functions from the top down in various forms of domination. The best expression of it can be found in the nation state and churches from the Christian paradigm (Castells 2004:7).

The founding and first ministry years of the URCSA Vlottenburg are characterised by this form of identity. A strong mother church that sends missionaries and pay for a minister to work among the poor farm labourers (and in so doing exercises control over the work) created this identity. It also legitimises the status quo in terms of ministry, leadership, structures and theological points of departure.

Resistance identity: This is an identity created by actors who have often been devalued and stigmatised by the logic of domination. They usually form communities (political parties) or rebel groups with the goal of resisting the opposition or suppression they experience. This usually occurs by building on identities that have already been defined by history, biology, faith, race or ethnic group. It is a defensive identity and finds expression in religious fundamentalism such as the Religious Right in the USA and Al-Qaeda in Islam countries (Castells 2004:8).

With the arrival of Minister C, the URCSA Vlottenburg started to construct this form of identity. The minister's theological training and points of departure gave him the tools to initiate this. In the manner in which he and the church council approached this and the processes that followed, it emerges that the 'resistance' in the identity construct led to various complexities and conflicts.

Project identity: This form of identity is built when social actors construct a new identity that redefines their position in society and, by doing so, also participate in the transformation of social structures. There are many examples, such as ecological movements and feminism. This form of identity produces 'subjects', in which subjects should not be understood as individuals, but as "collective social actors" through which the individual develops a holistic meaning of his/ her experience (Castells 2004:8).

In the story of the URCSA Vlottenburg, the research clearly indicates what happened during the past decade. The local leadership, in the absence of formal leadership in the form of a permanent minister, started working on a new identity and thereby also redefined its own position as faith community. In the process the leaders, as collective social actors, contributed to

20 Social movements are purposive collective actions of which the outcome, both in victory and in defeat, transforms the values and institutions of society. Because there is no sense of history other than the history that we sense, from an analytical perspective, there is no 'good' or 'bad' progressive or regressive social movements. (Castells 2004:104-111) 
the transformation of social structures (bridging and bonding social capital). ${ }^{21}$

From this it is also clear that the forming of identity of the faith community moved through various phases of 'construction' and is still developing. This brings one to the challenge of how the embodied leadership, given the congregation's marginalised and vulnerable situation, can contribute to the transformation agenda by crossing socio-economic and cultural boundaries.

\section{9.}

\section{EMBODIED LEADERSHIP IN 'ANOTHER WORLD'}

In the discussion of embodied leadership above I mentioned that I prefer to work with an understanding of leadership that does not entail a search for successful models or strategies, but that incorporates the awareness that leadership is often all about stumbling and falling. With this understanding of leadership I concur with the three elements that De Gruchy regards relevant when we reflect on leadership in 'another world', namely power, collaboration and a dialogical pedagogy, which I linked to the leadership of the URCSA Vlottenburg in the following section.

\subsection{Power}

According to Castells (2004:425-427), 'power' is in the process of being redefined and renegotiated all over the world. Various shifts are taking place, including shifts from physical power to intellectual power, from guns to information, and so forth. De Gruchy and Ellis (2008:18) are of the opinion that paying attention to power implies that relationship differences should be examined in terms of certain key factors. These differences include race, age, gender, language, nationality and professional status, and each has a unique influence on the exercising of power.

We all live with our own stories that are embedded in a greater social narrative encompassing differences in power and privilege, and we take these narratives with us into relationships. What is needed is greater transparency regarding these wider networks of power when we consider the future of embodied leadership. We must also be willing "to consciously frame them in a way that they can add to the richness of the tapestry rather than serve as barriers to dialogue and development" (De Gruchy \& Ellis 2008:18).

In the case of the URCSA Vlottenburg, the congregation is connected not only to the relationship with the old mother congregation, but also to relations within the church council, among families in leadership positions and in terms of the employee role in which many members function from day to day. The 'dependence syndrome' must be addressed and the acceptance of responsibility as active change agents of every member in the transformation process must be tabled (De Gruchy 2003:23). The theological language of (and appeal for) "discipleship"22 can play a key role here.

\subsection{Collaboration}

Collaboration $^{23}$ entails the conscious decision to resist the temptation of individualism. It is about teamwork, supporting one another and the ability to build other's capacity. The capacity of others is also developed during the process of attaining one's own goals as a leader (De Gruchy \& Ellis 2008:19).

21 From the empirical research one could see the social transformation taking place in the way in which members of the church board renegotiated positions of power in conversations with the DRC Stellenbosch West and other congregations in the circuit.

22 Cf. Cahalan and Nieman (2008:62-90).

23 Collaboration brings us to the theological importance of koinonia. See Brouwer (2009) for a lengthy discussion of the concept. 
Friedman (2007:51-55) concurs with this in his well-known work The world is flat, and it is particularly in his fourth "flattener", in the discussion of "uploading", that cooperation is also addressed. Instead of individuals and communities involved in "downloading", where the ideas and products of others are passively assumed or downloaded, "uploading" is a bottom-up approach. He writes: "Uploading is, without doubt, becoming one of the most revolutionary forms of collaboration in the flat world". He therefore refers to it as "a revolution of collaboration ... a massively emancipating move" (Friedman 2007:51-55).

The empirical study in this particular faith community confirmed that this is already happening on an intuitive level. The collective identity (koinonia) and cooperation are expressed in various ways in the faith community. Given the history of oppression, poverty and hardship that emerges in the stories, one can understand the fact that the community members stand together.

In terms of tools that can help with collaboration, the South African Partnership for Missional Churches (SAPMC) worked during the past five years on different spiritual practices and disciplines specifically aimed at helping congregations with collaboration (not only within the congregation itself, but also with partner congregations). This includes "dwelling in the world, dwelling in the Word and plunging" (Hendriks 2010:6).

From a theological point of view (a missio Dei perspective), the first focus is to determine what is happening in the world that God is sending his children to - thus a kind of cultural hermeneutics that works with "discovery, engagement, visioning and practice and growth". It in other words primarily concerns the development of "listening skills". ${ }^{24}$

The second focus is on the "dwelling in the Word", which consists of the reading of a chosen text for personal reflection and then sharing the personal reflection with a "reasonably friendlylooking stranger". This is later shared with the larger group, and the challenge is to discover the meaning of the text by asking: "What is God up to here?" and "What is the Word of God for us in this place and time?" The specific theological goal is to invite the participants into the world of the text, whereby they become part of the missio Dei (Keifert 2006:21, 36-37).

The second focus of "plunging" relates to the faith community's ability to cross cultural boundaries (conceptual and geographical). The purpose is to connect the faith community to its context and to what God is doing in that context in a new way. ${ }^{25}$ In the language of social capital, we have to do with both bridging and linking social capital.

\subsection{Dialogical pedagogy}

In the light of the first two challenges for embodied leadership, dialogical pedagogy refers to the attention that should be paid to the concerns and wisdom of ordinary people. In the words of Freire, with whom De Gruchy and Ellis (2008:18) concur: "The 'teachers' need to learn, and the learners' need to 'teach'". Knowledge and wisdom develop from discussion and dialogue. According to De Gruchy and Ellis (2008:18-19), a number of key elements are relevant here. They distinguish the following four, which I relate directly to the URCSA Vlottenburg's leadership's challenge:

Intentional: Attention needs to be paid to the equipment and capacity building of a present generation of leaders, but also to that of the future leaders. If the long history of dependence (and inequality) is not addressed, it simply confirms the unequal distribution of power that lies at the heart of poverty, neo-colonialism and globalisation.

Inclusive: To build up the leaders and their capacity, use must be made of the talents, gifts and resources available in the community (1 Cor 12 ). This inclusivity crosses the boundaries of 
gender, race, ethnicity, language and class. In the case of the Vlottenburg community, these boundaries are linked to historical divides in terms of class and colour and are still a very complex issue. But one must remember there is a big difference between the search for inclusivity and dealing with the tensions related to these divisions, and refusing to address it from fear that the status quo will be overturned.

Investing: In poor communities, financial capital investment is not a simple matter, as people lack the necessary material means (monetary capital). The fact remains that the average member has gifts, talents and skills (social capital) that can be invested in other ways in terms of presence, participation and involvement in the community. There is also the option of utilising the expertise and contributions of non-governmental organisations, other civic organisations, local government, donors, the DRC family on presbytery and synodical level, and so forth.

Integrity: This is about the manner in which leadership is practised and the underlying values the community strives for. If the faith community visualises itself as a community in which unity, justice, reconciliation and human dignity are important, a leadership that thwarts those values cannot serve it. There is an intrinsic link between the goal and the means.

The important role that the Belhar Confession has played in the URCSA for almost three decades cannot be ignored. The central aspects of this confession have over many years formed the theological foundation for ministry and practice in congregations throughout Southern Africa. In fact, there are denominations like the Reformed Church in America in the USA that have also accepted the Belhar Confession as part of its confessional foundation. The fact that Osmer (2005:90) discusses his analysis of the leadership in the URCSA Cloetesville under the title Leadership in the spirit of Belhar confirms the influence this confession has had on the practise of leadership in these specific communities.

\section{CONCLUSION}

If one begins to summarise these perspectives, it is clear that the empirical context of a local faith community, in the words of Brouwer (2009:1-5), consists of "a multi-layered texture that consists of influences at the macro, meso and micro levels of society". In this regard he uses the word ecology in the sense of geographic areas where people live, work, meet one another and entertain them. According to him, it is these changing ecologies that have an influence on faith communities.

He concurs with research by Ammermann ${ }^{26}$ and Eiesland ${ }^{27}$ and illustrates how faith communities react to these changes. Brouwer also points out the importance of understanding these changing ecologies. All kinds of factors can lead to the ecological changes of a faith community. Communities have to react and adjust to these changes. These adjustments lead to all kinds of dynamics and differentiations: It can lead to 'decay or vitality'. To prepare a congregation (and her leadership) to function missionally, it is in Brouwer's (2009:4) opinion necessary to do thorough empirical ethnographical research on the ecology of the community.

The different sources of data indicate that the community did not only react to ecological changes (at least in terms of the leadership), but also played a role in our country's transformation agenda as part of God's mission to the world. Different phases of leadership development occurred. Castells's third form of identity, the so-called project identity, offers unique challenges to the building of leadership potential and capacity by particularly focussing on power, collaboration and dialogical pedagogy as part of God's mission to the world. The

26 Ammerman, N.T. 2001. Congregations and community. Rutgers University Press: New Brunswick.

27 Eiesland, N.L. 2000. A particular place: Urban restructuring and religious ecology in a southern suburb. Rutgers University Press: New Brunswick. 
research takes place with the awareness that these challenges form part of an embodied ecclesiology by people who are vulnerable and fallible in the light of a long history of inequality.

In the introduction I referred to the events in the consistory before and during the worship service. The discussion above makes it clear that this is nothing else but a form of dialogical pedagogy. It is in such moments of vulnerable embodied leadership that one finds hope for the potential and capacity for future leadership development in a faith community called to be part of God's mission to the world. In imaginative ways, God sometimes surprises us precisely at the point where we are prepared to hand the leadership back to Him.

\section{BIBLIOGRAPHY}

Bonhoeffer, D. 1998. Sanctorum Communio. Dietrich Bonhoeffer Works. Vol. I. Minneapolis.

Brouwer, R. 2009. Geloven in gemeenschap: Het verhaal van een Protestanse geloofsgemeenschap. Kampen: Uitgeverij Kok.

Brouwer, R. 2009. Missional church and local constraints: A Dutch perspective. Verbum et Ecclesia , 30 (2), 1-5.

Cahalan, K.A. \& Nieman J.R. 2008. Mapping the Field of Practical Theology. In Bass, For life abundant (pp. 62-90). Grand Rapids: Eerdmans.

Caputo, J. 1993. Against Ethics: Contributions to a Poetics of Obligation with Constant Reference to Deconstruction. Indiana: University Press.

Castells, M. 2004 2nd edition. The Information Age: Economy, Society and Culture. Volume II: The Power of Identity. Oxford: Blackwell Publishing.

Cilliers, J. H. Fides Quaerens Corpralitatem: Perspectives on Liturgical Embodiment.

Cilliers, J. H. Fides Quarens Societatem: Praktiese Teologie op soek na sosiale belligaming.

De Gruchy, S. \& Ellis, W. 2008. Christian Leadership in 'Another Country': Contributing to an Ethical

Development Agenda in South Africa Today. In S. De Gruchy, From Our Side: Emerging Perspectives on Development and Ethics (pp. 9-20). Amsterdam: Rozenburg Publishers.

De Gruchy, S. 2003. Of agency, assets and appreciation: Seeking some commonalities between theology and development. Journal of Theology for Southern Africa , 117, 20-39.

Hendriks, H. J. 2010. Sustainable seminaries, reliable leadership. Stellenbosch University, Practical

Theology, Stellenbosch.

Hendriks, H. 2004. Studying Congregations. Wellington: Lux Verbi.

Henning, E. 2004. Finding your way in qualitative research. Pretoria: Van Schaik.

Kehane, A. 2010. Power and love: A Theory and Practice of Social Change. Cape Town: Tafelberg.

Lukken, G. 1990) Liturgie en Zintuiglijkheid: Over de betekenis van lichamelijkheid in de liturgie. Hileversum.

Marais, F. \& Taylor. P.T. 2007. Push through the Pain: The Spirit transforming churches across the world. Stellenbosch.

Osmer, R. 2005. The Teaching Ministry of Congregations. Louisville: Westminster.

Osmer, R. 2008. Practical Theology: An Introduction. Grand Rapids, Michigan: Eerdmans.

Smit, D. 2008. Mainline Protestantism in South Africa - and modernity: Tentative reflections for discussions. NGTT , 49 (1 \& 2), 92-105.

Swart, N. 2010. Mobilising faith-based organizations for social development through a pariticpatory actions (PAR) process. In N. R. Swart, Religion and Social Development in Post-apartheid South Africa: Perspectives for Critical Engagement. Stellenbosch: Sun Media.

Terreblanche, S. 2002. A History of Inequality in South Africa 1652-2002. Pietermaritzburg: University of Natal Press.

Van de Waal, K. 2009. Getting Going: Organizing Ethnographic Fieldwork. In S. Y. Ybema, Organizational Etnography: Studying the complexities of Everyday Life (pp. 5-25). Los Angeles: Sage.

Van der Leeuw, G. 1948. Sacramentstheologie. Nijkerk.

Vosloo, R. 2006. Body and health in the light of the theology of Dietrich Bonhoeffer. Religion and Theology , 13 (1), 23-37. 


\section{KEY WORDS}

Leadership

Ecclesiology

Congregation

Transformation

Paradigm shift

Socio-cultural changes

\section{TREFWOORDE}

Leierskap

Ekklesiologie

Gemeente

Transformasie

Partadigmaskuif

Sosiokulturele veranderinge 